\title{
THERMO-RESPIRATORY RESPONSES, HEMATOLOGICAL AND HORMONAL REACTIONS OF BUFFALO AND FRIESIAN CALVES TO THE RISE IN ENVIRONMENTAL TEMPERATURE
}

\author{
G. Ashour ${ }^{1}$, Laila R. Hassan ${ }^{2}$, Faiza I. Omran ${ }^{2}$ and M.M. Shafie ${ }^{1}$ \\ 1- Department of Animal Production, Faculty of Agriculture, Cairo University, \\ Egypt, 2 -Animal Production Research Institute, Egypt
}

\section{SUMMARY}

Five Egyptian buffalo calves (BC) and four Friesian calves (FC) were used to study the thermo-respiratory responses, hematological and hormonal reactions to diurnal, seasonal, and steady heat stress $\left(H S, 40^{\circ} \mathrm{C}\right)$ conditions. The study was carried out on the same animals at two stages of age, 9 and 18 months. The study comprised two experiments, the first one was carried out under natural environmental conditions (NC) during three months in winter and summer at each age. The second experiment was conducted under HS conditions continuously for 15 successive days every season for each age. The BC showed slight daily fluctuation in rectal temp. (RT) within the day. There was clear accordance between hair (HT), skin (ST) and air temp.(AT)during seasons and at diurnal times. Under HS, values of $H T$, ST and RT increased in both species and ages by 0.4-4.0 ${ }^{\circ} \mathrm{C}$. The respiration rate increased under heat stress to near two times the rate at winter morning for buffaloes, and five times for Friesian at 9 mo. of age, while the rate increased nearly three times at 18 mo. in both species. The BC had higher hematocrit values than FC under all the thermal conditions and ages. The values of hemoglobin were lower in winter than in summer in both species and ages. There were clear species differences in all values of red and white blood cells in the two seasons and HS conditions. The FC had higher values of the monocytes, esinophils, and the ratio neutrophils/lymphocytes than BC, under $H S$. At any age, BC had greater concentration of $T_{3}$ and lower concentration of $T_{4}$ than $F C$ under the NC. Heat stress induced reduction in $T_{3}$ in both species with more response of $B C$, down to $60 \%$ of that at hot summer. The correlation coefficients between the studied traits were determined. It is clear from this study that the effects of specie, age and environmental air temperature were significant on thermo-respiratory responses with sporadic effects on hematological and hormonal traits.

Keywords: Buffalo, cattle, heat stress, season, blood, hormones

\section{INTRODUCTION}

High ambient temperature is one of the most important problems for animal production in tropical and subtropical countries. Numerous physiological changes occur in response to hot environmental conditions. Neurons that are temperature sensitive are located throughout the animal's body and send information to the hypothalamus which evokes numerous physiological and behavioral responses in attempt to maintain body heat balance (Curtis, 1983). Heat stress influences the performance of animal by reducing feed intake, life weight gain and feed efficiency

Issued by The Egyptian Society of Animal Production 
(Ashour et al., 2000) and by increasing the respiratory rate (Shafie and El-Sheikh Aly, 1970, Ashour, 1990, Kamal et al., 1993, Ashour et al., 1998 ,) These responses have a deleterious effect on both production and physiologic status of the cow (West, 2003).

Hormonal alterations occur with heat stress but it is often difficult to separate effects of lower fed dry matter intake (DMI) and direct effects of heat stress. McGuire et al. (1991) reported a tendency for plasma somatotropin to decline with heat stress but no difference is due to restricted DMI, while triiodothyronine concentration declined with heat and with restricted feed intake. Some authors have shown declines in triiodothyronine and thyroxine when animals were exposed to high ambient temperatures (Magdub et al., 1982, El-Masry and Habeeb, 1989, and Kamal et al., 1993).

The objectives of this work are to study the thermo-respiratory responses of buffalo and Friesian calves to both diurnal and seasonal thermal climatic conditions as well as to steady heat stress and to interpret the relationship between these responses, and relevant hematological and hormonal reactions.

\section{MATERIALS AND METHODS}

This study was carried out at the Experimental Farm belonging to Animal Physiology Research Lab., Animal Production Department, Faculty of Agriculture, Cairo University, Giza, Egypt.

\section{1-Experimental animals and management:}

Five Egyptian buffalo calves (BC) and four Friesian calves (FC) were available for the present study. At the beginning of the experiment, the age of all animals was 9 mo., their body weight (BW) ranged between 139 and $165 \mathrm{~kg}$ for $\mathrm{BC}$ and between 153 and $170 \mathrm{~kg}$ for FC. The body surface area (SA) of these calves was calculated on the bases of BW according to the equation derived by Berman(2003), $\mathrm{SA}=0.14$ $\times \mathrm{W}^{0.57}$ as presented in Table (1). The study was carried out on the same animals at two stages of age, 9 and 18 months. Table (1) shows the BW of the calves at these two ages. A commercial concentrated ration was offered twice a day at 09:00 $\mathrm{h}$ and at $17: 00 \mathrm{~h}$. It was offered at a rate of $4 \%$ of the BW of animals as recommended by NRC (1981) requirements. The nutrient contents of the ration were approximately $16 \%$ crude protein, $3 \%$ crude fat and $15 \%$ crude fiber. Animals were offered Egyptian clover (Berseem, Trifolium alexandrinum) during winter replaced in summer by maize green fodder ( Darawa, Zea maize). Rice straw was offered ad libtium for free choice consumption . Drinking fresh water was offered twice a day.

\section{2-Experimental design:}

The study includes two experiments; the first one was executed under natural environmental conditions (NC) during three months in winter and summer seasons at each age. The average air temperature (AT) and relative humidity $(\mathrm{RH})$ within these seasons are shown in Table (2). The second experiment was conducted under steady heat stress ( $\mathrm{HS}, 40^{\circ} \mathrm{C}$ ) conditions in controlled temperature lab. This lab. was equipped with four heaters controlled by a highly sensitive digital thermostat to maintain a steady temperature of $40 \pm 1^{\circ} \mathrm{C}$. A ceiling fan was applied to assure allover homogenous indoors temperature. An extraction fan rotation was adjusted to keep the indoors $\mathrm{RH}$ around $60 \%$. Animals were kept and maintained under these conditions 
inside this lab. Continuously for 15 successive days every season for each age ( 9 and 18 months).

Table 1. Means \pm S.E of body weight $(\mathrm{BW}, \mathrm{Kg})$ and body surface area $\left(\mathrm{SA}, \mathrm{m}^{2}\right)$ of buffalo and Friesian calves at 9 and 18 months of age under natural and stress thermal conditions

\begin{tabular}{ccccccc}
\hline \multirow{2}{*}{ Items } & \multicolumn{5}{c}{ Buffalo } & \multicolumn{3}{c}{ Friesian } \\
\cline { 2 - 7 } & Winter & Summer & Stress & Winter & Summer & Stress \\
\hline BW & $139.0 \pm 9.0$ & $165.0 \pm 3.0$ & $145.0 \pm 6.0$ & $153.0 \pm 7.0$ & $128.0 \pm 3.0$ & $169.0 \pm 11.0$ \\
SA & $2.33 \pm 0.15$ & $2.57 \pm 0.04$ & $2.38 \pm 0.3$ & $2.22 \pm 0.05$ & $2.36 \pm 0.09$ & $2.61 \pm 0.43$ \\
\hline & & 9 months & \\
\hline BW & $297.0 \pm 6.0$ & $320.6 \pm 8.0$ & $307.0 \pm 9.0$ & $331.0 \pm 22.0$ & $316.0 \pm 6.0$ & $305.8 \pm 8.0$ \\
SA & $3.54 \pm 0.04$ & $3.71 \pm 0.08$ & $3.66 \pm 0.02$ & $3.82 \pm 0.32$ & $3.69 \pm 0.04$ & $3.65 \pm 0.12$ \\
\hline
\end{tabular}

Table 2. Natural air temperature $\left(\mathrm{AT},{ }^{\circ} \mathrm{C}\right)$ and relative humidity $(\mathrm{RH}, \%)$ at two day times during winter and summer seasons at experimental tests

\begin{tabular}{lcccc}
\hline \multirow{2}{*}{ Items } & \multicolumn{2}{c}{ Winter } & \multicolumn{2}{c}{ Summer } \\
\cline { 2 - 5 } & $\mathbf{0 8 : 0 0 h}$ & $\mathbf{1 4 : 0 0 h}$ & $\mathbf{0 8 : 0 0 h}$ & $\mathbf{1 4 : 0 0 h}$ \\
\hline AT & $19.4 \pm 1.2$ & $23.8 \pm 1.3$ & $24.5 \pm 0.52$ & $32.0 \pm 0.75$ \\
RH & $69.2 \pm 0.52$ & $64.4 \pm 0.72$ & $67.0 \pm 0.82$ & $60.4 \pm 1.15$ \\
\hline
\end{tabular}

\section{3-Thermo-physiological responses:}

Under natural seasonal (winter and summer) conditions, thermo-physiological responses (rectal, RT; skin, ST; and hair, HT temperatures, ${ }^{\circ} \mathrm{C}$ ) and respiration rate (RR, resp./min) were recorded twice a day at $08: 00 \mathrm{~h}$ and $14: 00 \mathrm{~h}$ in two consecutive days at weekly intervals during each season (3 months). Blood samples were collected once a week at 08:00h-09:00h.During the second experiment, 15 days inside the controlled temperature lab., the above mentioned responses were tested daily between 08:00h $-09: 00 \mathrm{~h}$ and 14:00h-15:00h., while blood samples were collected daily at 08:00h-09:00h.

\section{4-Hematological responses:}

Blood samples were collected in heparinized tubes from the external jugular vein. Directly, a portion of the blood was used for determining hemoglobin concentration $(\mathrm{Hb})$, hematocrit value(Ht), red blood cells count(RBCs), white blood cells count (WBCs), alongside a blood smear prepared for differential counts of leukocyte types (lymphocytes, neutrophils, eosinophils, basophils and monocytes).

\section{5-Thyroid hormones:}

The blood samples were centrifuged for $30 \mathrm{~min}$. at 3000 r.p.m. Clear plasma samples were stored at $-20^{\circ} \mathrm{C}$ until the assay of thyroxine $\left(\mathrm{T}_{4}\right)$ and triiodothyronine $\left(\mathrm{T}_{3}\right)$ hormones concentration by using RIA technique applying Kits of Diagnostic Products Corporation (DPC), Los Angeles, CA, USA. 


\section{6-Statistical analysis:}

The data were analyzed by least square analysis of variance using the General Linear Models procedure of the Statistical Analysis System, SAS (1990).

\section{RESULTS}

1-Body surface area:

The values of body SA, ranged between $\left(2.22\right.$ to $\left.2.57 \mathrm{~m}^{2}\right)$ for the 9 mo. calves and $\left(3.54\right.$ to $3.82 \mathrm{~m}^{2}$ ) for the $18 \mathrm{mo}$. calves with no appreciable species difference (Table, $1)$.

\section{2-Thermal responses:}

Seasonal and daily means of HT and ST are presented in Table (3). There was clear accordance between HT and ST and AT in seasonal diurnal rhythm. The HT and ST values, in the two species and two ages, were the lowest in winter morning (the coldest ambient temperature) and the highest in summer afternoon (Table, 3). The temperatures of these traits showed intermediate degrees at both winter afternoon $(14: 00 \mathrm{~h})$ and summer morning $(08: 00 \mathrm{~h})$, under almost, the same environmental temperature (Table, 2). There were significant age differences, in the two species, being the highest at age 9 mo. and the lowest at age 18 mo.

Table 3. Means + S.E. of rectal $(\mathrm{RT})$, hair $(\mathrm{HT})$ and skin (ST) temperatures $\left({ }^{\circ} \mathrm{C}\right)$ and respiration rate (RR,resp./min) of buffalo and Friesian calves at 9 and 18 months of age under natural and stress thermal conditions

\begin{tabular}{|c|c|c|c|c|c|c|c|}
\hline \multirow{2}{*}{\multicolumn{2}{|c|}{ Items }} & \multicolumn{3}{|c|}{ Buffalo } & \multicolumn{3}{|c|}{ Friesian } \\
\hline & & Winter & Summer & Stress & Winter & Summer & Stress \\
\hline \multicolumn{8}{|c|}{9 months } \\
\hline \multirow{2}{*}{ RT } & $08: 00 \mathrm{~h}$ & $38.0 \pm 0.4$ & $38.1 \pm 0.1$ & $38.4+0.2$ & $38.2 \pm 0.2$ & $38.7 \pm 0.1$ & $40.2 \pm 0.1$ \\
\hline & $14: 00 h$ & $38.4 \pm 0.1$ & $39.0 \pm 0.1$ & $39.0 \pm 0.1$ & $39.2 \pm 0.1$ & $39.6 \pm 0.1$ & $40.8 \pm 0.1$ \\
\hline \multirow{2}{*}{ HT } & $08: 00 \mathrm{~h}$ & $33.1 \pm 1.3$ & $34.7 \pm 0.2$ & $36.1 \pm 0.5$ & $32.5 \pm 0.2$ & $35.3 \pm 0.3$ & $37.7 \pm 0.1$ \\
\hline & $14: 00 h$ & $35.4 \pm 0.2$ & $36.6 \pm 0.2$ & $37.0 \pm 0.2$ & $34.00+0.2$ & $36.8+0.2$ & $38.4 \pm 0.2$ \\
\hline \multirow{2}{*}{ ST } & $08: 00 \mathrm{~h}$ & $36.1 \pm 0.3$ & $35.5 \pm 0.2$ & $37.0 \pm 0.1$ & $36.5 \pm 0.2$ & $37.5 \pm 0.1$ & $38.6 \pm 0.1$ \\
\hline & $14: 00 h$ & $37.1 \pm 0.2$ & $37.0+0.1$ & $37.9 \pm 0.1$ & $37.5+0.2$ & $38.3 \pm 0.1$ & $39.3 \pm 0.1$ \\
\hline \multirow{2}{*}{$\mathbf{R R}$} & $08: 00 \mathrm{~h}$ & $26.0 \pm 3.5$ & $23.8 \pm 0.6$ & $40.2 \pm 2.6$ & $22.8 \pm 0.7$ & $36.6 \pm 1.8$ & $89.0 \pm 4.7$ \\
\hline & $14: 00 \mathrm{~h}$ & $30.5+3.1$ & $31.3 \pm 0.7$ & $51.4+2.8$ & $29.3+1.1$ & $49.7 \pm 2.5$ & $111.4+4.6$ \\
\hline \multicolumn{8}{|c|}{18 months } \\
\hline \multirow{2}{*}{ RT } & $08: 00 \mathrm{~h}$ & $37.7 \pm 0.1$ & $37.5 \pm 0.1$ & $38.6+0.1$ & $38.2+0.2$ & $38.5+0.1$ & $39.4 \pm 0.1$ \\
\hline & $14: 00 \mathrm{~h}$ & $38.5+0.1$ & $38.2 \pm 0.1$ & $39.1+0.1$ & $38.8+0.1$ & $39.1+0.1$ & $40.0 \pm 0.1$ \\
\hline \multirow{2}{*}{ HT } & $08: 00 \mathrm{~h}$ & $31.2 \pm 0.4$ & $35.1 \pm 0.1$ & $36.1 \pm 0.2$ & $34.3 \pm 0.3$ & $35.2 \pm 0.2$ & $37.4 \pm 0.1$ \\
\hline & $14: 00 h$ & $32.8 \pm 0.4$ & $35.9 \pm 0.2$ & $36.8 \pm 0.1$ & $33.3 \pm 0.3$ & $36.4 \pm 0.2$ & $38.1 \pm 0.1$ \\
\hline \multirow{2}{*}{ ST } & $08: 00 \mathrm{~h}$ & $35.0 \pm 0.2$ & $35.5 \pm 0.1$ & $37.2 \pm 0.1$ & $35.6 \pm 0.3$ & $36.3 \pm 0.1$ & $38.0 \pm 0.1$ \\
\hline & $14: 00 h$ & $36.0 \pm 0.2$ & $36.9+0.1$ & $37.9 \pm 0.1$ & $36.5+0.2$ & $37.2 \pm 0.2$ & $38.6 \pm 0.1$ \\
\hline \multirow{2}{*}{ RR } & $08: 00 \mathrm{~h}$ & $18.6 \pm 0.3$ & $20.9 \pm 0.5$ & $43.9 \pm 2.3$ & $28.8 \pm 3.1$ & $31.1 \pm 2.4$ & $69.1 \pm 3.3$ \\
\hline & $14: 00 \mathrm{~h}$ & $24.1+0.8$ & $32.2+1.1$ & $63.2+3.5$ & $31.1+2.4$ & $41.4+1.9$ & $91.1+3.3$ \\
\hline
\end{tabular}

There was higher RT at (14:00h) in summer than at the other times (Table, 3), whereas the lowest values were recorded at $(08: 00 \mathrm{~h})$ in winter. At $(14: 00 \mathrm{~h})$ the highest RT reached by some of the $\mathrm{BC}$ were 38.5 and $39.0^{\circ} \mathrm{C}$ in winter and summer, respectively, compared with higher values, 39.2 and $39.6^{\circ} \mathrm{C}$, in $\mathrm{FC}$ respectively. The $\mathrm{BC}$ showed slight daily fluctuation within the day than that of the $\mathrm{FC}$. The daily fluctuations in RT were more at afternoon than in the morning by $\left(0.4-0.8^{\circ} \mathrm{C}\right)$ in 
winter and $\left(0.7-0.9^{\circ} \mathrm{C}\right)$ in summer for buffaloes vs. $\left(0.6-1.0^{\circ} \mathrm{C}\right)$ and $\left(0.6-0.9^{\circ} \mathrm{C}\right)$ for Friesian, at 9 and 18 mo. of age respectively.

Under HS $\left(40^{\circ} \mathrm{C}\right)$, there were higher values for HT, ST and RT in both species and ages than the values for the outdoors responses (Table, 3). Table (4) shows the extent of increase in the body temperatures (RT, HTand ST) in response to the rise in environmental AT. It is evident that at younger age $(9 \mathrm{mo}$.), the calves of both species are susceptible to the rise in AT than at their elder age $(18 \mathrm{mo}$.). On the other hand, the buffaloes showed low levels of change than Friesians, a clear evidence of adaptation to hot conditions. This adaptive capability of buffaloes is prominent in case of respiration rate (RR), where the Friesian showed more than $100 \%$ increase in RR vs. slight increase in buffalo (Table, 4 ).

Table 4. Extent of increase in body temperatures (RT,HT and ST, ${ }^{\circ} \mathrm{C}$ ) and respiratory rate (RR,resp./min) of buffalo and Friesian calves in response to levels of rise in environmental air temperature (AT). (computed from Tables 2 and 3)

\begin{tabular}{ccccc}
\hline \multirow{2}{*}{ Body temperatures } & \multicolumn{4}{c}{ Environmental air temperature } \\
\cline { 2 - 5 } & $\begin{array}{c}\text { Sum.evening-Win.morning } \\
\mathbf{3 2}^{\mathbf{0}} \mathbf{C}-\mathbf{1 9}^{\mathbf{0}} \mathbf{C}\end{array}$ & $\begin{array}{c}\text { Heat stress-Sum. evening } \\
\mathbf{4 0}^{\mathbf{0}} \mathbf{C}-\mathbf{3 2}^{\mathbf{0}} \mathbf{C}\end{array}$ \\
\cline { 2 - 5 } & Buffalo & Friesian & Buffalo & Friesian \\
\hline RT & 1.0 & $\mathbf{9}$ months & 1.2 \\
HT & 3.5 & 0.4 & 0.0 & 1.6 \\
ST & 0.9 & 4.3 & 0.4 & 1.0 \\
RR & 5.3 & 1.8 & 0.9 & 61.7 \\
\% of increase & 20 & 118 & 20.1 & 124 \\
\hline RT & 0.5 & 0.9 & 0.9 & 0.9 \\
HT & 4.8 & 2.1 & 0.9 & 1.7 \\
ST & 1.9 & 1.6 & 1.0 & 1.4 \\
RR & 13.6 & 12.6 & 31.0 & 49.7 \\
\% of increase & 73 & 44 & 96 & 72 \\
\hline
\end{tabular}

Note: $\%$ of increase in body temperatures is not computed since the ceiling of change is strictly controlled at low values, particularly rectal temp.

\section{3-Respiratory response:}

The responses of respiration rates of $\mathrm{BC}$ and $\mathrm{FC}$ under seasonal $\mathrm{NC}$ and $\mathrm{HS}$ temperatures are presented in Table (3). Under NC, at afternoon (14:00h) the highest rate encountered for some $\mathrm{BC}$ in winter and summer were 24.1 and $32.2 \mathrm{resp}$. $/ \mathrm{min}$., respectively compared to that of FC, 29.3 and 49.7 resp./min., showing clear species difference in summer. The 9 months old BC showed the highest RR in the two seasons compared to the older calves, meanwhile the age effect in FC was found only during summer.

Under HS, the RR was faster at 14:00h than at 08:00h. The FC showed increase in RR than BC by 22.4 vs. 11.2 resp./min. and by 22.0 vs. 19.3 resp. $/ \mathrm{min}$. at 9 and 18 months of age respectively (Table, 3 ). The RR of FC was faster than that of $\mathrm{BC}$ at the 
two testing times, with greater species difference in the 9 mo. calves, nearly about $100 \%$ faster in Friesians than in buffaloes.

Table (4) shows the dramatic increase in RR of the young FC in reaction to the rise in environmental temperature in a struggle to maintain normal RT. The older FC did not show such a huge trouble. This case of the young FC is apt to cause dangerous change in internal $\mathrm{pH}$ alongside water balance. This calls for proper managerial attention for young Friesians.

\section{4-Hematological responses:-}

Table (5) shows seasonal and heat stress effects on $\mathrm{Ht}, \mathrm{Hb}$ values and $\mathrm{RBCs}$ of $\mathrm{BC}$ and $\mathrm{FC}$. The $\mathrm{BC}$ had higher Ht values than $\mathrm{FC}$ under all the thermal conditions and ages. The values of $\mathrm{Hb}$ concentrations were lower in winter than in summer in both species and ages. The average values in winter and summer were 11.25 and $13.25 \mathrm{~g} / \mathrm{dl}$., respectively in buffaloes and 11.1 and $12.3 \mathrm{~g} / \mathrm{dl}$. in Friesians. The buffaloes showed clear tendency to increase $\mathrm{Hb}$ concentration with age progress, on the contrary the Friesian showed clear drop, under the NC.

Table 5. Responses of hematocrit value $(\mathrm{Ht}, \%)$, hemoglobin concentration $(\mathrm{Hb}$, g/dl) and red blood cells count $\left(\mathrm{RBCs} \times 10^{6} / \mathrm{mm}^{3}\right)$ of buffalo and Friesian calves at 9 and 18 months of age under natural and stress thermal conditions (Means+ S.E.)

\begin{tabular}{ccccccc}
\hline \multirow{2}{*}{ Items } & \multicolumn{5}{c}{ Buffalo } & \multicolumn{3}{c}{ Friesian } \\
\cline { 2 - 7 } & Winter & Summer & Stress & Winter & Summer & Stress \\
\hline Ht & $30.0 \pm 0.6$ & $31.6 \pm 1.0$ & $31.7 \pm 0.6$ & $30.4 \pm 1.4$ & $27.5 \pm 0.8$ & $26.2 \pm 0.7$ \\
Hb & $9.3 \pm 0.3$ & $12.3 \pm 0.5$ & $12.8 \pm 0.3$ & $12.8 \pm 0.5$ & $13.2 \pm 0.3$ & $10.7 \pm 0.5$ \\
RBCs & $7.5 \pm 0.0$ & $6.4 \pm 0.2$ & $6.4 \pm 0.1$ & $6.3 \pm 0.3$ & $6.1 \pm 0.2$ & $5.6 \pm 0.2$ \\
\hline \multicolumn{7}{c}{$\mathbf{1 8 ~ m o n t h s}$} \\
\hline Ht & $34.0 \pm 0.5$ & $33.0 \pm 0.5$ & $31.0 \pm 0.5$ & $25.0 \pm 1.8$ & $30.3 \pm 1.0$ & $29.3 \pm 0.4$ \\
Hb & $13.2 \pm 0.2$ & $14.2 \pm 0.4$ & $13.1 \pm 0.2$ & $9.4 \pm 0.0$ & $11.4 \pm 0.6$ & $10.8 \pm 0.3$ \\
RBCs & $7.0 \pm 0.1$ & $7.0 \pm 0.1$ & $7.0 \pm 0.3$ & $6.0 \pm 0.3$ & $6.0 \pm 0.1$ & $5.3 \pm 0.1$ \\
\hline
\end{tabular}

The average values of RBCs were higher in winter than in summer in the 9 mo. old $\mathrm{BC}$. There was clear species difference in all values of RBCs in the two seasons being 7.0 vs. $6.0 \times 10^{6} / \mathrm{mm}^{3}$ in winter and 6.4 vs. $6.0 \times 10^{6} / \mathrm{mm}^{3}$ in summer for buffaloes and Friesians, respectively.

Heat stress caused clear drop in RBCs count in FC $\left(5.6\right.$ and $\left.5.3 \times 10^{6} / \mathrm{mm}^{3}\right)$ for 9 and 18 mo. calves, respectively compared to that outdoors. On the contrary, this stress did not show effect on BC $\left(6.4\right.$ and $\left.7.0 \times 10^{6} / \mathrm{mm}^{3}\right)$ compared to that outdoors, respectively (Table 5).

There were differences in the percentages of leukocyte types due to changes in thermal conditions during summer and winter seasons. Basophils( $\mathrm{Ba}$ ) were few in the two species and at all conditions, not more than 1.0\%. Generally, FC had higher values of the monocytes (Mo) and eosinophils (Eo). Heat stress induced drop in neutrophils $(\mathrm{Ne}) \%$ concomitant with the rise in lymphocytes(Ly)\%, in both species and at the two ages. Generally, FC had higher values of the Ne: Ly ratio than BC (Table 6). 


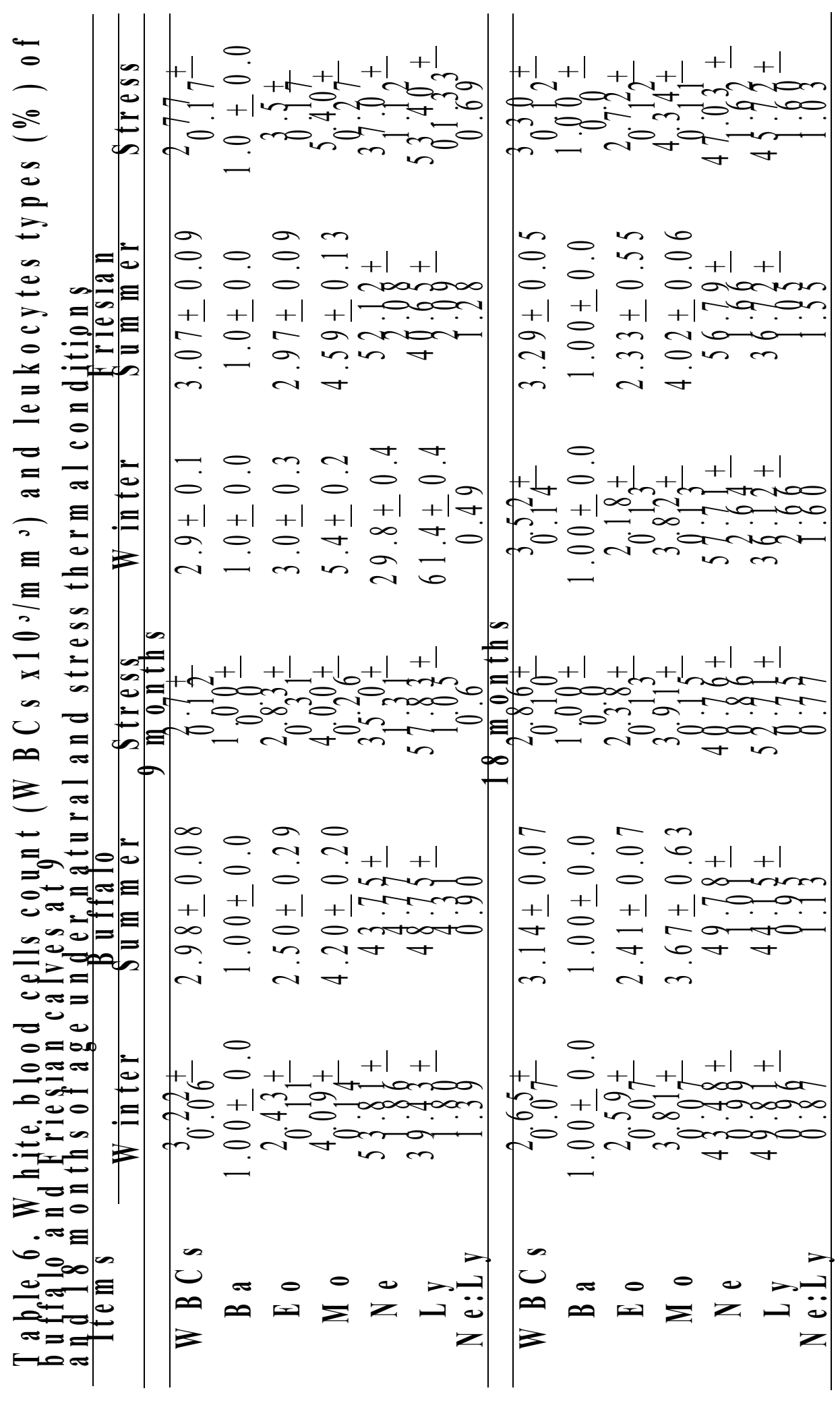




\section{5-Thyroid activity:}

Table (7) shows the concentration values of $\mathrm{T}_{3}$ and $\mathrm{T}_{4}$ hormones. The two species had greater values of $T_{3}$ in summer than in winter, and the values were smaller in the younger calves. Generally, at any age $\mathrm{BC}$ had greater concentration of $\mathrm{T}_{3}$ and lower concentration of $\mathrm{T}_{4}$ than $\mathrm{FC}$ under the NC. It is clear from Table (7) that buffaloes decreased the $\mathrm{T}_{3}$ concentration under HS whereas $\mathrm{FC}$ did not experience this reaction, it seems that the reaction of buffaloes is adaptability to hot conditions.

Table 7. Triiodothyronine $\left(T_{3}, n g / d l\right)$ and thyroxine $\left(T_{4}, \mu g / d l\right)$ hormones of buffalo and Friesian calves at 9 and 18 months of age under natural and stress thermal conditions

\begin{tabular}{ccccccc}
\hline \multirow{2}{*}{ Items } & \multicolumn{5}{c}{ Buffalo } & \multicolumn{3}{c}{ Friesian } \\
\cline { 2 - 7 } & Winter & Summer & Stress & Winter & Summer & Stress \\
\hline \multirow{2}{*}{$\mathbf{T}_{\mathbf{3}}$} & 99.90 & 149.0 & 97.75 & $\mathbf{9}$ months & 112.46 & 114.75 \\
& \pm 16.83 & \pm 16.26 & \pm 21.19 & - & \pm 12.11 & \pm 5.27 \\
$\mathbf{T}_{\mathbf{4}}$ & 6.42 & 5.13 & 7.22 & & 10.09 & 9.44 \\
& \pm 0.93 & \pm 1.72 & \pm 1.09 & - & \pm 0.78 & \pm 0.66 \\
\hline & 146.66 & 157.77 & 96.84 & 104.60 & 138.81 & 133.00 \\
$\mathbf{T}_{\mathbf{3}}$ & \pm 17.96 & \pm 17.70 & \pm 14.93 & \pm 18.20 & \pm 8.12 & \pm 12.57 \\
& 5.51 & 5.10 & 4.89 & 5.66 & 9.67 & 9.26 \\
$\mathbf{T}_{\mathbf{4}}$ & \pm 0.29 & \pm 0.34 & \pm 0.39 & \pm 0.29 & \pm 0.46 & \pm 0.77 \\
\hline
\end{tabular}

Table (8) shows the statistical analysis of variance (ANOVA) for the responses of the studied traits to the affecting factors (specie, age, and environmental air temperature) as well as the integrated effects of interactions of these factors. It is clear from the Table that the effects were significant on thermo-respiratory responses with sporadic effects on hematological and hormonal traits.

Table 8. ANOVA for the level of the physiological responses to the factors affecting

\begin{tabular}{ccccccc}
\hline Physiological & \multicolumn{3}{c}{ Factors } & \multicolumn{3}{c}{ Interactions } \\
\cline { 2 - 7 } responses & $\mathbf{S p}$ & $\mathbf{A T}$ & Age & $\mathbf{S p} \times \mathbf{A T}$ & $\mathbf{S p} \times \mathbf{A g e}$ & $\mathbf{A T} \times \mathbf{A g e}$ \\
\hline $\mathbf{R T}$ & $* *$ & $*$ & $* *$ & $*$ & $* *$ & $* *$ \\
$\mathbf{H T}$ & $* *$ & $* *$ & $* *$ & $* *$ & $* *$ & $* *$ \\
$\mathbf{S T}$ & $* *$ & $* *$ & $* *$ & $* *$ & $* *$ & $* *$ \\
$\mathbf{R R}$ & $* *$ & $* *$ & $* *$ & $* *$ & $* *$ & $* *$ \\
$\mathbf{H t}$ & $* *$ & $\mathrm{~ns}$ & $* *$ & $\mathrm{~ns}$ & $\mathrm{Ns}$ & $\mathrm{ns}$ \\
$\mathbf{H b}$ & $* *$ & $*$ & $\mathrm{~ns}$ & $\mathrm{~ns}$ & $* *$ & $\mathrm{~ns}$ \\
$\mathbf{T}_{\mathbf{3}}$ & $\mathrm{ns}$ & $\mathrm{ns}$ & $* *$ & $\mathrm{~ns}$ & $\mathrm{Ns}$ & $\mathrm{ns}$ \\
$\mathbf{T}_{\mathbf{4}}$ & $* *$ & $\mathrm{~ns}$ & $\mathrm{~ns}$ & $\mathrm{~ns}$ & $\mathrm{Ns}$ & $\mathrm{ns}$ \\
\hline
\end{tabular}

Sp : Species AT: Air temperature ns : Not-significant

$*$ : Significant at $(\mathrm{P}<0.05) \quad * *$ : Significant at $(\mathrm{P}<0.01)$

There were negative correlations between body SA and RT and RR, $(-0.108$ and 0.273 , respectively), being significant only with RT. The high positive correlation coefficient (0.502) between RT and RR indicates important biological interactions. 
The significant negative correlation of $\mathrm{Hb}$ with RT (-0.113) is another mechanism for controls of RT. Negative correlations were found between $\mathrm{T}_{3}$ and RT, and between $\mathrm{T}_{4}$ and RT, (-0.12 and -0.02 , respectively), anyhow these correlation values are not significant (Table 9).

Table 9. Correlation coefficients $(R)$ between the physiological traits in relevance with rectal temperature

\begin{tabular}{cc} 
Traits & $\mathbf{R}$ \\
\hline $\mathrm{SA}$ and RT & $-0.108^{*}$ \\
$\mathrm{SA}$ and RR & -0.273 \\
$\mathrm{RR}$ and RT & $0.502^{* *}$ \\
$\mathrm{Hb}$ and RT & $-0.113^{*}$ \\
$\mathrm{~T}_{3}$ and RT & -0.120 \\
$\mathrm{~T}_{4}$ and RT & -0.020 \\
\hline
\end{tabular}

*Significant at $(\mathrm{P}<0.05)$. $* *$ Significant at $(\mathrm{P}<0.01)$.

\section{DISCUSSION}

All the calves, of the two species, showed the same pattern of physiological reactions to the surrounding thermal condition -in the present study- cold (18.1$\left.20.7^{\circ} \mathrm{C}\right)$, comfort $\left(23.6-25.5^{\circ} \mathrm{C}\right), \operatorname{hot}\left(30.9-33^{\circ} \mathrm{C}\right)$, Table $(2)$, and steady HS $\left(40^{\circ} \mathrm{C}\right)$ .The temperature values at winter afternoon were almost close to those at summer morning, 23.6 and $25.5^{\circ} \mathrm{C}$, respectively. The temperatures at these daily times are within the comfort zone of environmental temperature for bovines. The comfort zone is from 50 to $80^{\circ} \mathrm{F}\left(10.1\right.$ to $26.9^{\circ} \mathrm{C}$ ) in the case of typical tropical type cattle (Findlay, 1953 and Brody, 1956). Shafie and Badreldin (1963), in Egypt, stated that ambient temperature $\left(22\right.$ to $\left.27^{\circ} \mathrm{C}\right)$ is the upper critical limit of the thermal comfort zone for both Egyptian cattle and buffaloes. Berman et al. (1985) and Igono et al. (1992) indicated that the upper critical AT for dairy cows is 25 to $26^{\circ} \mathrm{C}$.

It is clear that HT and ST showed greater values at 9 mo. than at $18 \mathrm{mo}$. of age, this is in accordance with changes, in proportional SA (Table, 1) and in hair coat characteristics with advancement of age. The SA of the animal is the inter-phase for skin convective, radiant and evaporative heat loss, complemented by convective and evaporative heat loss via the respiratory system (Berman, 2003). The SA is a component of thermal exchange models (McGovern and Bruce, 2000, and Gebremehdin and $\mathrm{Wu}, 2001)$. It is interesting to find clear accordance between HT, ST and AT during seasons and at diurnal times. Shafie and El Sheikh Aly (1970), Sayah (1997) and Ashour et al. (1998) reported that there were highly significant diurnal and seasonal variations in HT.

Under HS, Table (3) shows increase in HT, ST and RT in both species and ages by $0.4-4^{\circ} \mathrm{C}$. Aggarwal and Upadhyay (1998) found that exposure of buffaloes to direct solar radiation increased RT by $2.8^{\circ} \mathrm{C}$. When animals are exposed to rising AT the first response observed was increase in RR(Ashour,1990), in the present study the gradually rising AT from $19^{\circ} \mathrm{C}$ to $40^{\circ} \mathrm{C}$ caused a progressive increase in RR. The RR increased under HS to near two times the rate at winter morning for buffaloes, and five times for Friesians at 9 mo. of age, while the rate increased nearly three times at 18 mo. of age in both species. Aggarwal and Upadhyay(1998) found that the exposure of buffaloes to direct solar radiation increased respiratory frequency to 4.5 
fold. The RR was augmented drastically by HS, that of Friesians was clearly faster than that of buffaloes at the two testing times (08:00 and 14:00h), under HS. This species difference was concomitant with similar species-age trend in the response of RT. This is clear evidence of better heat tolerance capacity of buffaloes than Friesians. West (2003) reported that, the genetic selection for heat tolerance may be possible, on the other hand, continued selection for greater productive performance in the absence of consideration for heat tolerance will result in greater susceptibility to heat stress.

Ominski et al. (2002) reported that daily body temperature and RR of cattle were increased by $0.6 \pm 0.04^{\circ} \mathrm{C}$ and $27 \pm 1.3$ breaths/min., respectively, during short-term heat exposure. Mitlohner et al. (2001 and 2002), stated that the RR was lower in shaded than in unshaded heifers $(\mathrm{p}<0.05)$. The significant increase in the RR under HS enables animals (Ayrshire calves) to dissipate the excess of body heat by vaporizing more moisture in the expired air, which accounts for about $30 \%$ of the total heat dissipation (Mclean, 1963). However, the excessive respiratory activity may cause respiratory alkalosis as a result of excessive $\mathrm{CO}_{2}$ output and consequently loss of blood alkali reserve. Schneider et al. (1988) reported that, cows exposed to HS in environmental chambers exhibited a diurnal variation in blood $\mathrm{pH}$ and blood bicarbonate levels, closely following the cow's RT and RR. With increasing environmental temperature, the RR continues to rise linearly until a certain temperature, where the rate of increase in RR slows, and then it almost levels off or slightly decreases (Kibler, 1962 and Biance, 1963). At this level, the respiratory muscles reach a threshold of maximum activity and thus the RR cannot increase further.

Values of $\mathrm{Ht}, \mathrm{Hb}$ and RBCs showed slight variation due to HS (Table, 5). However, buffaloes showed clear tendency of increase in these traits with age progress, in contrary the Friesians showed no consistent trend. Generally, FC had higher percentage of Mo. and Eo. Under HS, the Ne percentage decreased while that of Ly increased. Mitlohner et al. (2002) also noted a decrease in the percentage of circulating neutrophils for shaded compared with unshaded heifers.

Table (7) shows greater values of $\mathrm{T}_{3}$ concentrations in summer than in winter for the two species, being higher in $\mathrm{BC}$ than $\mathrm{FC}$. While, $\mathrm{T}_{4}$ showed a reverse seasonal case in $\mathrm{BC}$. This higher concentration of $\mathrm{T}_{3}$ in summer in spite of the hot temperature is questionable; it may be due to the particular green fodder in summer not available in winter. The suggestion needs rational experimentation. It is clear that HS induced reduction in $\mathrm{T}_{3}$ in both species, with more response of buffaloes, down to $60 \%$ of that at hot summer. The $\mathrm{T}_{3}$ hormone had low concentration at the younger age than at older age while, $\mathrm{T}_{4}$ showed opposite pattern (Table 7). However, if the concentrations are considered in proportional to the BW (Table, 10) the ratio will be in favor of the younger.

Table 10. $T_{3} /$ body weight ratio of buffalo and Friesian calves under natural and stress thermal conditions

\begin{tabular}{cccccc}
\hline \multirow{2}{*}{ AGE } & \multicolumn{2}{c}{ Buffalo } & Friesian & \multicolumn{2}{c}{ Stress } \\
\cline { 2 - 6 } & Winter & Summer & Summer & Buffalo & Friesian \\
\hline $\mathbf{9} \mathbf{~ m o .}$ & 0.72 & 0.90 & 0.88 & 0.67 & 0.68 \\
$\mathbf{1 8} \mathbf{~ m o .}$ & 0.50 & 0.50 & 0.44 & 0.32 & 0.43 \\
\hline
\end{tabular}


Thyroid hormones $\left(\mathrm{T}_{3}\right.$ and $\left.\mathrm{T}_{4}\right)$ are released into the circulation by a simple diffusion process, of the total hormone released, about $90 \%$ is $\mathrm{T}_{4}$ and $10 \%$ is $\mathrm{T}_{3}$ (Kaneko, 1997). Under certain conditions, thyroxine is preferentially monodeiodnated by a $5^{\prime}$ deiodinase to $3.3^{\prime}, 5^{\prime}$ - triiodothyronine. Since this form of $\mathrm{T}_{3}$ formed by target cells is biologically inactive, monodeiodination to form reverse $\mathrm{T}_{3}$ provides a mechanism to attenuate the metabolic effects of thyroid hormones, thus more $T_{3}$ is available to the target tissue cells than $T_{4}$. Once within the tissue cells, $T_{3}$ is more potent than $\mathrm{T}_{4}$, but its duration action is shorter (Reece, 1991).

\section{CONCULSION}

It could be concluded from this study that the effects of specie, age and environmental air temperature were significant on thermo-respiratory responses with sporadic effects on hematological and hormonal traits. This work evidenced that buffaloes have better heat tolerance capacity than Friesians and their adaptive capability is more prominent. Also, the study proved that the proper managerial attention is necessitated for younger calves, particularly for temperate breeds under Egyptian conditions.

\section{REFERENCES}

Aggarwal, A. and R.C.Upadhay, 1998. Studies on evaporation heat losses from skin and pulmonary surfaces in male buffaloes exposed to solar radiations. Buffalo J.,2:179.

Ashour G., 1990.Water balance in bovine as related to heat regulation. Ph.D. Thesis, Fac. Agric., Cairo Univ., Giza, Egypt.

Ashour G., S. A. Fawzy; E.A.Omar and M.S. Sayah, 1998. Physiological reactions of weaned Friesian calves in different housing types. Egyptian J. Anim. Prod., 35, Suppl. Issue:47.

Ashour, G., L.R.Hassan, F.I.Omran and M.M.Shafie (2000). Growth performance of buffalo and Friesian calves under natural climatic and steady heat stress conditions. J. Agric. Sci. Mansoura Univ., 25:2503.

Berman A., 2003. Effects of body surface area estimates on predicted energy requirements and heat stress. J. Dairy Sci.,86:3605.

Berman, A., Y. Folman, M. Kain, M. Mamem, Z.Herz, D. Wolfenson, A. Ariele, and Y. Graber, 1985. Upper critical temperatures and forced ventilation effects for high-yielding dairy cows in a subtropical climate. J. Dairy Sci.,68:1488.

Bianca W., 1963. Rectal temperature and respiratory rate as an indicators of heat tolerance in cattle. J.Agric.Sci.,60:113.

Brody S., 1956. Climatic physiology of cattle. J. Dairy Sci.,39:715.

Curtis S.E., 1983. Environmental Management in Animal Agriculture, The Iowa State Univ. Press, Ames, USA.

El-Masry K.A. and A.A.M. Habeeb, 1989.Thyroid function in lactating Friesian cows and water buffaloes under winter and summer Egyptian conditions. $3^{\text {rd }}$ EgyptianBritish Conf.Anim., Fish, Poult. Prod., 7-10 October, 1989, Alexandria, Egypt, p.613.

Findlay J.D., 1953. The effect of climate on cattle and their productivity. N.A.A.S. Quarterly Review, No. 19, p.285. 
Gebremehdin K.G. and B.Wu., 2001. A model of evaporative cooling of wet skin surface and fur layer. J.Thermal Biol., 26:537.

Igono M.O., G. Bjotvedt and H.T. Sanford-Crane, 1992. Environmental profile and critical temperature effects on milk production of Holstein cows in desert climate. Int. J. Biometeorol., 36:77.

Kamal T.H., M.K. Shebaita and I.I. Ibrahim, 1993. Seasonal variations in different physiological parameters in water buffaloes and Friesians. Proc. Inter. Symp., 912 November, 1992, Cairo, Egypt, EAAP Publication No.62:201

Kaneko J.J. 1997. Clinical Biochemistry of Domestic Animals, Replika Press Pvt Ltd., India, Chapter (21).

Kibler, H.H., 1962. Energy metabolism and related thermoregulatory reactions to thermal stress in $50^{\circ}$ and $80^{\circ} \mathrm{F}$ acclimated dairy heifers. Mo. Agric. Exp. Sta. Res. Bull.,793.

Magdub A., H.D. Johnson and R.L. Belyea, 1982. Effect of environmental heat and dietary fiber on thyroid physiology of lactating cows. J. Dairy Sci.,65:2323.

McGovern R.R. and J.M. Bruce, 2000. A model of the thermal balance for cattle in hot conditions. J.Agric. Eng. Res., 77:81.

McGuire M.A., D.K. Beede, R.J. Collier, F.C. Buonomo, M.A. Delorenzo, C.J. Wilcox, G.B. Huntington and C.K. Reynolds, 1991. Effects of acute thermal stress and amount of feed intake on concentrations of somatotropin, insulin-like growth factors (IGF)-I and IGF-II, and thyroid hormones in plasma of lactating Holstein cows. J.Anim.Sci.,69:2050.

Mclean J.A., 1963. The regional distribution of cutaneous moisture vaporization in the Ayrshire calf. J. Agric. Sci., 78:303.

Mitlohner F.M., M.L. Galyean and J.J. McGlone, 2002. Shade effects on performance, carcass traits, physiology, and behavior of heat-stressed feedlot heifers. J. Anim. Sci., 80:2043.

Mitlohner F.M., J.L. Morrow, J.W. Dailey, S.C. Wilson, M.L. Galyean, M.F. Miller and J.J. McGlone, 2001. Shade and water misting effects on behavior, physiology, performance, and carcass traits of heat-stressed feedlot cattle. J. Anim. Sci., 79:2327.

NRC, 1981. Effect of Environment on Nutrient Requirements of Domestic Animals. National Academy Press, Washington, DC.,USA.

Ominski K.H., A.D. Kennedy, K.M. Wittenberg and S.A. Moshtaghi Nia, 2002. Physiological and production responses to feeding schedule in lactating dairy cows exposed to short-term, moderate heat stress. J. Dairy Sci.,85:730.

Reece W.O., 1991. Physiology of Domestic Animals, Lea and Febiger, Philadelphia, USA.

SAS, 1990. Statistical Analysis System Institute, Inc., Cary, Nc.,USA.

Sayah M.S., 1997. Physiological responses of Friesian calves to different environmental conditions in Delta region. M.Sc. Thesis, Fac. Agric., Cairo Univ., Giza, Egypt.

Schneider P.L., D.K. Beede and C.J. Wilcox, 1988. Nycterohemeral patterns of acidbase status, mineral concentrations and digestive function of lactating cows in natural or chamber heat stress environments. J. Anim. Sc.,66:112.

Shafie M.M. and A.L. Badreldin, 1963. Skin temperature gradients in bovines. Proc. $2^{\text {nd }}$ Anim. Prod. Conf., 3-10 March., (1963), Cairo, Egypt, p.4. 
Shafie M.M. and L.M. El-Sheikh Aly, 1970. Heat tolerance of Friesian cattle under Egyptian climatic conditions. Egyptian. J. Anim. Prod., 10:99.

West J.W., 2003. Effects of heat-stress on production in dairy cattle. J. Dairy Sci., $86: 2131$. 


\title{
إستجابة حرارة الجسم والتتفس وخصائص الام والهرمونات في عجول الجاموس والفريزيان لإرتفاع
}

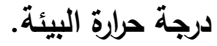

\author{
جمال عاثور ', ليلي رشاد حسن', فايزة ابراهيم عمران ومحمد محمود الثافعي' \\ 1 - قسم الانتاج الحيواني، كلية النزاعة، جامعة القاهرة، مصر، ب -معطه بحوث الاتتاج الحيواني، وزارة النراعة، مصر \\ استخدم في هذه التجربـة ه عجول جاموسى و ء عجول فريزيـان لدراسـة استجابة حرارةالجسم والتنفس

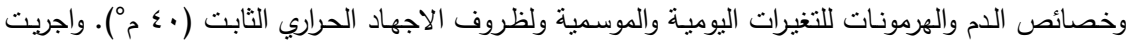

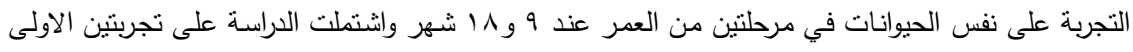

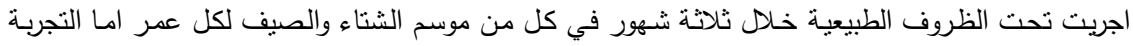

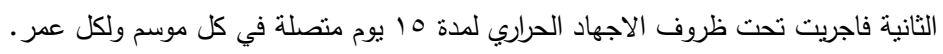

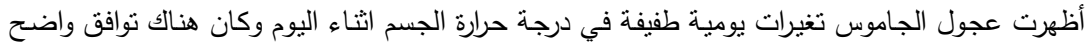

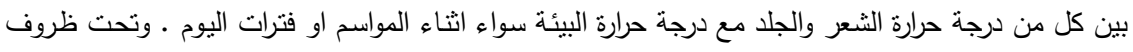

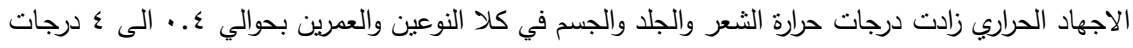

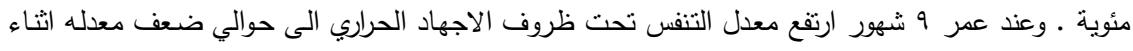

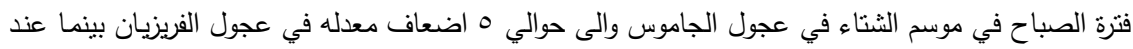 \\ عمر 11 ا شهر ارتقع معدل التنفس الى حوالي ثلاثة اضعاف في كلا النوعين.

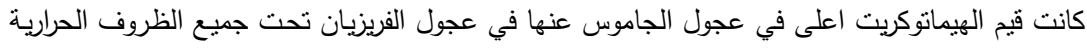

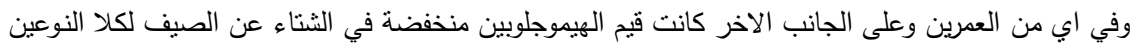

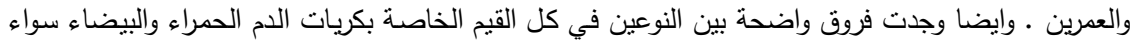

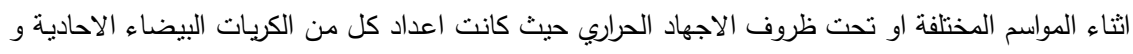

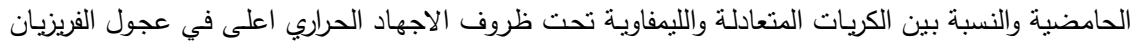

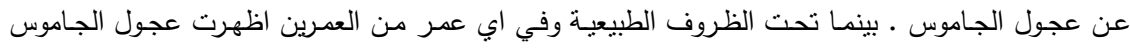

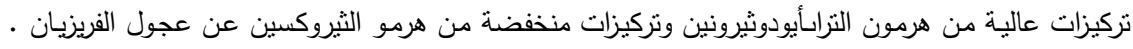

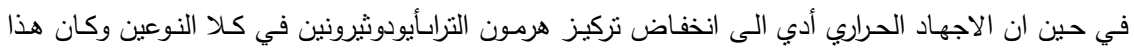

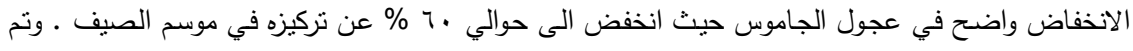

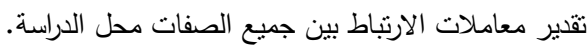

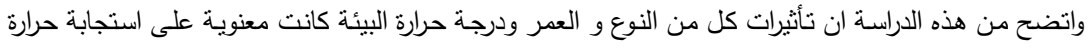

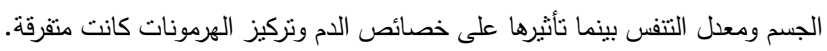


Table 6. White blood cells count (WBCs $\left.x 10^{3} / \mathrm{mm}^{3}\right)$ and leukocytes types (\%) of buffalo and Friesian calves at 9 and 18 months of age under natural and stress thermal conditions

\begin{tabular}{|c|c|c|c|c|c|c|}
\hline \multirow[t]{2}{*}{ Items } & \multicolumn{3}{|c|}{ Buffalo } & \multicolumn{3}{|c|}{ Friesian } \\
\hline & Winter & Summer & Stress & Winter & Summer & Stress \\
\hline \multicolumn{7}{|c|}{9 months } \\
\hline WBCs & $3.22 \pm 0.06$ & $2.98 \pm 0.08$ & $2.7 \pm 0.12$ & $2.9 \pm 0.1$ & $3.07 \pm 0.09$ & $2.77 \pm 0.17$ \\
\hline $\mathbf{B a}$ & $1.00 \pm 0.0$ & $1.00 \pm 0.0$ & $1.00 \pm 0.0$ & $1.0 \pm 0.0$ & $1.0 \pm 0.0$ & $1.0 \pm 0.0$ \\
\hline Eo & $2.43 \pm 0.11$ & $2.50 \pm 0.29$ & $2.83 \pm 0.31$ & $3.0 \pm 0.3$ & $2.97 \pm 0.09$ & $3.5 \pm 0.17$ \\
\hline Mo & $4.09 \pm 0.14$ & $4.20 \pm 0.20$ & $4.00 \pm 0.26$ & $5.4 \pm 0.2$ & $4.59 \pm 0.13$ & $5.40 \pm 0.27$ \\
\hline $\mathrm{Ne}$ & $53.81 \pm 1.86$ & $43.7 \overline{5 \pm} 4.77$ & $35.0 \pm 1.31$ & $29.8 \pm 0.4$ & $52.12 \pm 2.08$ & $37.0 \pm 1.12$ \\
\hline Ly & $39.43+1.80$ & $48.75 \pm 4.31$ & $57.83+1.05$ & $61.4 \pm 0.4$ & $40.65 \pm 2.09$ & $53.40 \pm 01.33$ \\
\hline Ne:Ly & $1 . \overline{39}$ & $0 . \overline{9} 0$ & 0.6 & $0 . \overline{4} 9$ & $1 . \overline{2} 8$ & $0 . \overline{6} 9$ \\
\hline \multicolumn{7}{|c|}{18 months } \\
\hline WBCs & $2.65 \pm 0.07$ & $3.14 \pm 0.07$ & $2.86 \pm 0.10$ & $3.52 \pm 0.14$ & $3.29 \pm 0.05$ & $3.30 \pm 0.12$ \\
\hline $\mathbf{B a}$ & $1.00 \pm 0.0$ & $1.00+0.0$ & $1.00+0.0$ & $1.00+0.0$ & $1.00+0.0$ & $1.00 \pm 0.0$ \\
\hline Eo & $2.59 \pm 0.07$ & $2.41 \pm 0.07$ & $2.38 \pm 0.13$ & $2.18 \pm 0.13$ & $2.33 \pm 0.55$ & $2.72 \pm 0.12$ \\
\hline Mo & $3.81 \pm 0.07$ & $3.67 \pm 0.63$ & $3.91 \pm 0.15$ & $3.82 \pm 0.13$ & $4.02 \pm 0.06$ & $4.34 \pm 0.11$ \\
\hline $\mathrm{Ne}$ & $43.48+0.99$ & $49.78+1.01$ & $40.76+0.86$ & $57.71+2.64$ & $56.79+1.66$ & $47.03+1.62$ \\
\hline Ly & $49.81 \pm 0.96$ & $44.15 \pm 0.95$ & $52.71 \pm 0.75$ & $36.12 \pm 2.66$ & $36.72 \pm 1.05$ & $45.72 \pm 1.60$ \\
\hline Ne:Ly & $0 . \overline{8} 7$ & $1 . \overline{13}$ & $0 . \overline{7} 7$ & $1 . \overline{6} 0$ & $1 . \overline{5} 5$ & $1 . \overline{0} 3$ \\
\hline
\end{tabular}



Proc. $12^{\text {th }}$ Conf. Egyptian Soci. Anim. Prod. Mansoura, Egypt, 29/11- 2/12/2004,1-

Issued by The Egyptian Society of Animal Production 